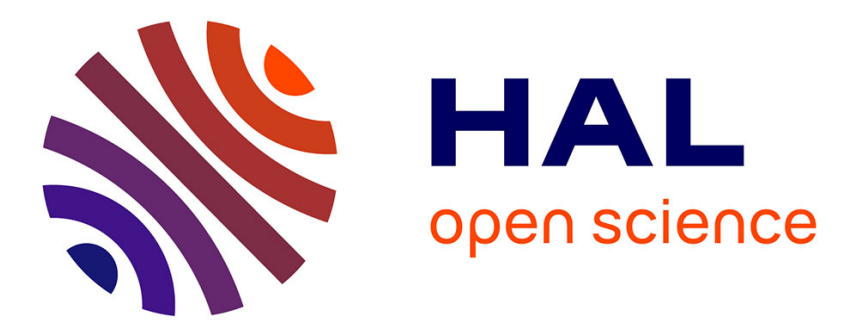

\title{
Interaction between local and regional pollution during Escompte 2001: Impact on surface ozone concentrations (IOP2a and 2B)
}

\author{
F. Cousin, Pierre Tulet, R. Rosset
}

\section{- To cite this version:}

F. Cousin, Pierre Tulet, R. Rosset. Interaction between local and regional pollution during Escompte 2001: Impact on surface ozone concentrations (IOP2a and 2B). Atmospheric Research, 2005, 74 (1-4), pp.117-137. 10.1016/j.atmosres.2004.04.012 . hal-00519392

\section{HAL Id: hal-00519392 \\ https://hal.science/hal-00519392}

Submitted on 15 Jun 2021

HAL is a multi-disciplinary open access archive for the deposit and dissemination of scientific research documents, whether they are published or not. The documents may come from teaching and research institutions in France or abroad, or from public or private research centers.
L'archive ouverte pluridisciplinaire HAL, est destinée au dépôt et à la diffusion de documents scientifiques de niveau recherche, publiés ou non, émanant des établissements d'enseignement et de recherche français ou étrangers, des laboratoires publics ou privés.

\section{(c)(1)}

Distributed under a Creative Commons Attribution| 4.0 International License 


\title{
Interaction between local and regional pollution during Escompte 2001: impact on surface ozone concentrations (IOP2a and $2 b$ )
}

\author{
F. Cousin ${ }^{\mathrm{a}, *}$, P. Tulet ${ }^{\mathrm{b}}$, R. Rosset ${ }^{\mathrm{a}}$ \\ ${ }^{a}$ Laboratoire d'Aérologie/OMP, UMR 5560 CNRS Université de Toulouse III, France \\ ${ }^{\mathrm{b}}$ CNRM/GMEI Météo-France Toulouse, France
}

Escompte, a European programme which took place in the Marseille region in June-July 2001, has been designed as an exhaustive database to be used for the development and validation of air pollution models. The air quality Mesoscale NonHydrostatic Chemistry model (Meso-NH-C) is used to simulate 2 days of an Intensive Observation Period (IOP) documented during the Escompte campaign, June 23 and 24, 2001. We first study the synoptic and local meteorological situation on June 23 and 24, using surface and aircraft measurements. Then, we focus on the pollution episode of June 24. This study emphasizes the deep impact of synoptic and local dynamics on observed ozone concentrations. It is shown that ozone levels are due both to regional and local factors, with highlights of the importance of ozone layering. More generally this confirms, even in an otherwise predominant local sea-breeze regime, the need to consider larger scale regional pollutant transport.

Keywords: Air pollution modelling; Regional transport; Sea-breeze; Ozone layers

* Corresponding author. Fax: +33 561332790 .

E-mail addresses: frederic.cousin@aero.obs-mip.fr (F. Cousin), rosr@aero.obs-mip.fr (R. Rosset). 


\section{Introduction}

Escompte is a European programme designed to generate an exhaustive database for the development and validation of air pollution models (Cros et al., 2004). The region of Marseille/Fos/Berre is characterized by a complex topography subject to channelling effects and sea-breeze circulations (Fig. 1). There are strong industrial sources (the Berre pond accounts for $25 \%$ of the French Volatil Organic Compound (VOC) production), the large Marseille urban area (1 million inhabitants), a dense road and motorway network and strong biogenic emission sources. This domain has been selected for its frequent and intensive summer photochemical pollution episodes. Four Intensive Observation Periods (IOP) have been identified, the most significant being IOP $2 \mathrm{a} / \mathrm{b}$, a 6-day complex pollution episode.

In summer, frequent regional recirculations of pollution occur in the western Mediterranean basin, due to topography and meteorological conditions. These phenomena have been deeply documented (Millàn et al., 1997), in particular around the Iberian peninsula.

Our aim here is to show how such circulations interact with local effects such as seabreeze regimes in the Escompte domain, resulting for example in the pollution episode observed on June 24 (IOP2b).

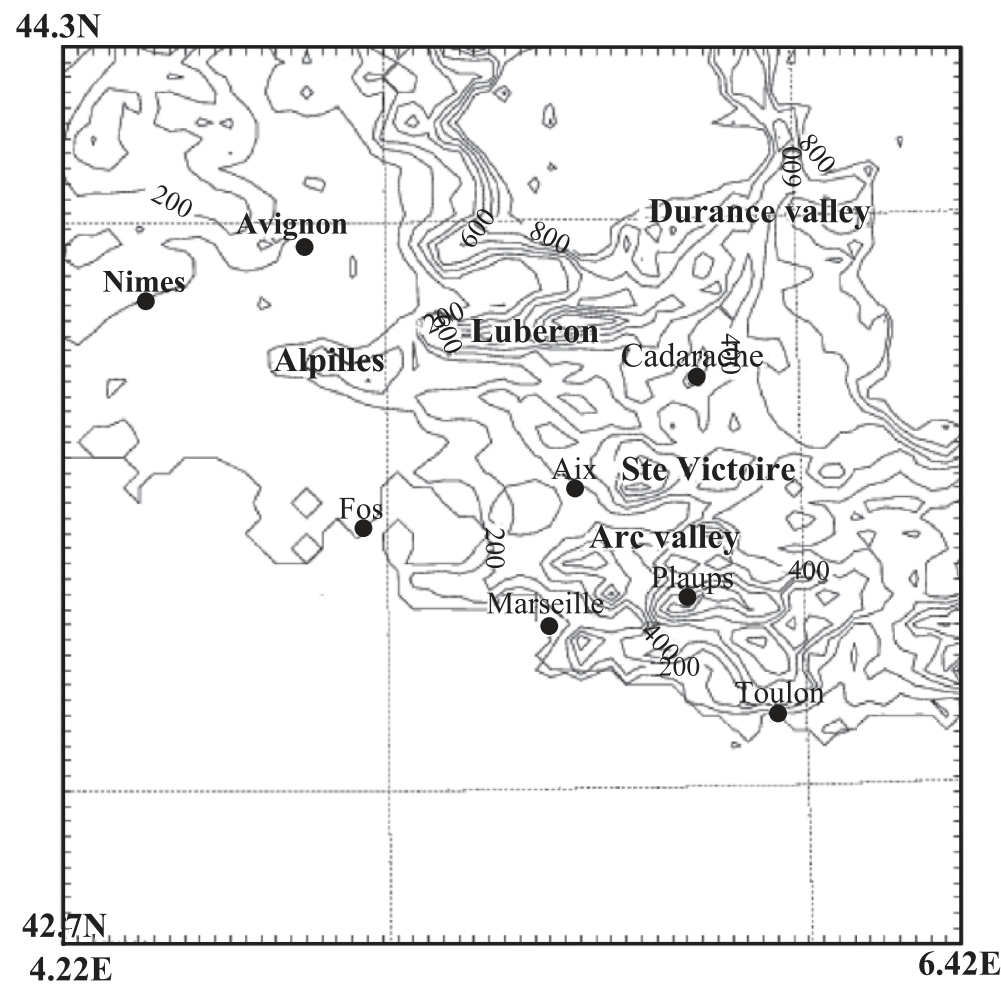

Fig. 1. Orographic map (height isocontours) of the central Escompte domain with its main stations, valleys and massifs quoted in the text. 
With this aim, we have used a 3D mesoscale model coupled on-line with a chemistry module (Section 2). The full Escompte database (surface, aircraft and lidar measurements) was used to validate these 3D simulations. Multi-scale modelling was necessary to capture both the synoptic (Section 3) and local sea-breeze circulations (Section 4) of the complex pollution episode of June 24. Their combination and impact on atmospheric pollution are then studied in Section 5.

\section{The Mesoscale Nonhydrostatic Chemistry (Meso-NH-C) model}

Simulations have been made using the Meso-NH model jointly developed by CNRM (Meteo-France) and Laboratoire d'Aerologie (CNRS) (Lafore et al., 1998). A turbulent kinetic energy equation is solved for the evolution of the boundary layer (Bougeault and Lacarrère, 1989). The ISBA parameterisation (Noilhan and Mahouf, 1995) holds for the surface sensible and latent heat fluxes. The TEB (Town Energy Budget) scheme accounting for anthropogenic sensible and latent heat fluxes due to industrial and traffic activities, and specifically designed for urban parameterisations, is also used (Masson, 2000). The gas phase chemical module ReLACS (Crassier et al., 2000) derived from RACM (Stockwell et al., 1997) is coupled on-line with Meso-NH (Tulet et al., 2003). The Genemis anthropogenic emission inventory (Wickert et al., 1999) at $9 \mathrm{~km}$ resolution was used.

The Meso-NH-C model is supplemented with a module of lagrangian diagnoses (Gheusi and Stein, 2002). Briefly, these latter are not based on the computation of individual trajectories but rather on the on-line computation of three Eulerian passive tracers initialised with the Cartesian coordinates of each grid cell. This 'initial coordinates' method allows at any later time for the individual identification of each Lagrangian air parcel by referring to its initial position. In our particular case, this method efficiently allows for the tracking of air parcel trajectories in a stratified medium such as the lower atmosphere, as will be shown.

Two-way grid nested simulations are performed between a large (Fig. 2) and a small (Fig. 1) domain. The large domain (9 km resolution) in Fig. 2 between latitudes $40.8^{\circ} \mathrm{N}$ and $47^{\circ} \mathrm{N}$ and longitudes $1.06^{\circ} \mathrm{E}$ and $10.02^{\circ} \mathrm{E}$, incorporates intense regional pollution sources such as Barcelona, Marseille, Lyon and the Po valley. The embedded Escompte small domain ( $3 \mathrm{~km}$ resolution) centered on Marseille and the Berre pond (Fig. 1) is located between latitudes $42.7^{\circ} \mathrm{N}$ and $44.3^{\circ} \mathrm{N}$ and longitudes $4.22^{\circ} \mathrm{E}$ and $6.42^{\circ} \mathrm{E}$. There are 54 vertical levels, 40 of which in the boundary layer between the surface and $2500 \mathrm{~m}$.

The crucial problem of chemical initialisation in pollution simulations is solved by using the global chemistry transport model MOCAGE (Dufour et al., 2004) which also gives boundary conditions to Meso-NH-C accounting for transboundary fluxes.

\section{Synoptic overview}

On June 21, there is a north-west regime at $500 \mathrm{hPa}$ with a ridge extending from Spain to Great Britain, and a surface low located north of Italy, a situation at the origin of the 
(a)

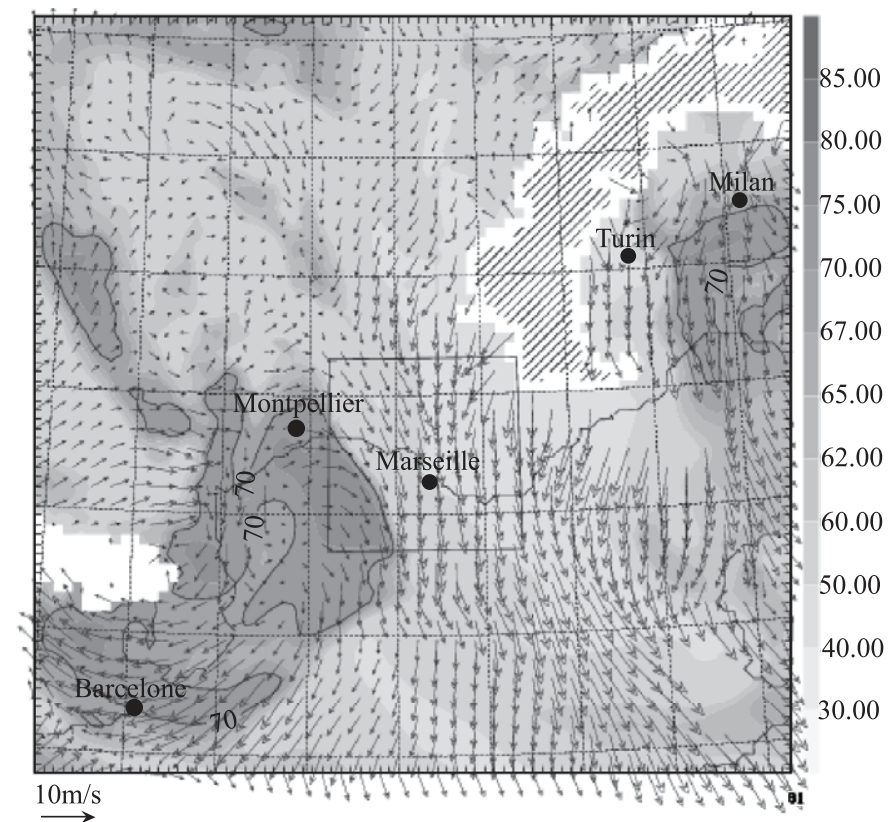

(b)

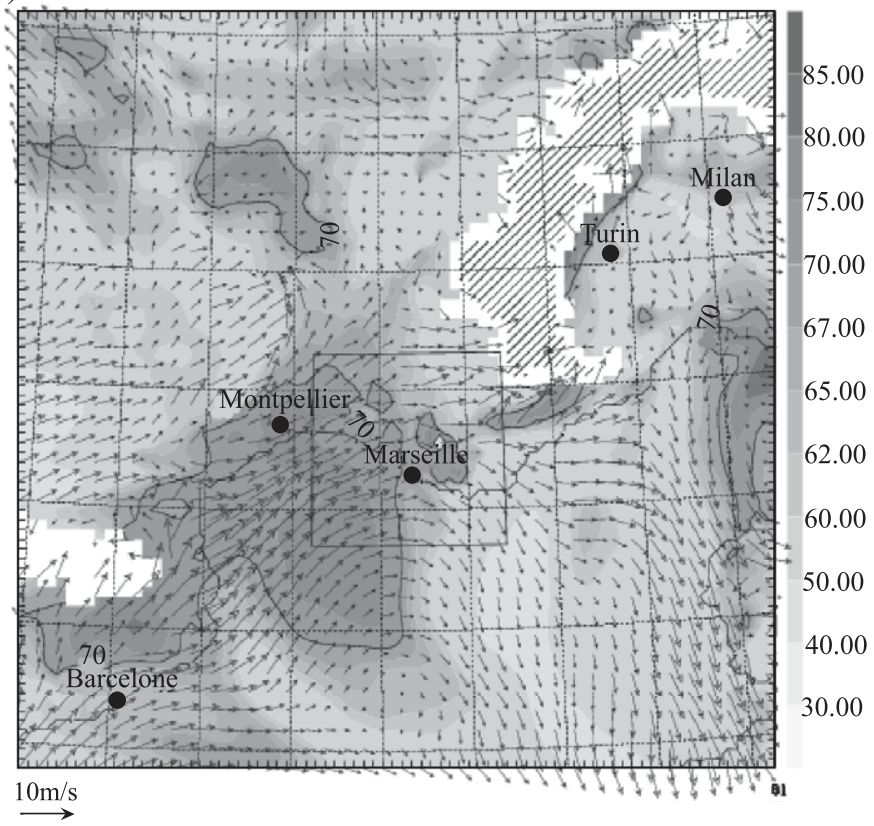

Fig. 2. Ozone concentrations at $1500 \mathrm{~m}$ (scales in ppb at the right) with superimposed wind fields (vector length at bottom left is for $10 \mathrm{~m} / \mathrm{s}$ ) on (a) June 24 at 00.00 UTC (after $71 \mathrm{~h}$ of simulation) and (b) June 24 at 12.00 UTC (after $83 \mathrm{~h}$ of simulation). The square delineates the small domain. 
mistral wind blowing in the lower Rhône valley and Marseille. By June 22 and 23, the above ridge has moved to a position from Gibraltar to Ireland with an extended $1013 \mathrm{hPa}$ flat low over the Mediterranean sea. On June 24, the ridge, now from Morocco to Belgium, is associated with north-west winds over the western Mediterranean sea. At the surface, anticyclonic conditions $(1020 \mathrm{hPa})$ are prevailing with moderate winds favourable to the onset of sea-breeze circulations. Such a dynamic situation is clearly explained by Gangoiti et al. (2001). Specifically, our study takes place at the end of a mistral period in the Escompte domain and the onset of a sea-breeze regime on June 24.

For such typical dynamical situations as the one from June 21 to 23, Millàn et al. (1996, 1997) explain how layering processes occur in the Western Mediterranean Basin (WMB). The WMB is surrounded by high coastal mountains. In summer, during daytime conditions, Atlas mountains at the south and eastern Iberian mountains are strongly heated, favouring the early formation of up-slope winds which combine with sea-breezes and their compensatory return flows (with subsidence over the coast and at sea), thus generating recirculations. These processes result in the formation of elevated ozone layers along the coast. Layering has been documented to reach $2-3 \mathrm{~km}$ in depth and extend out over the sea to more than $300 \mathrm{~km}$. At night, land-based processes die out and the layers formed on the previous day(s) can drift along the coast, acting as reservoir layers of aged pollutants. Accumulation and ageing of pollutants in the low troposphere have been described by Gangoiti et al. (2001), especially between the Balearic islands and east of the Iberian peninsula. For instance, Fig. 2 displays simulated ozone concentrations at $1500 \mathrm{~m}$ with superimposed wind vectors, the square around Marseille delineating the small domain. On June 24 at 00.00 UTC (diagram a), high ozone concentrations ( $80 \mathrm{ppb)}$ ) are simulated west of the Mediterranean basin. Finally, the sea breeze on next morning brings the lower layers inland, closing the recirculations. It is clear that these recirculations have an impact on the ozone levels observed in the WMB: one will show how such recirculations contribute to the ozone levels observed in the Escompte domain on June 24. In diagram b, during the day, the westerly fluxes move the polluted layers along the coast, towards south-eastern France, thus invading the whole Escompte domain.

\section{Local dynamical evolution between June 23 and 24, 2001}

\subsection{The transition period during June 23}

On June 23, a challenge for simulations lies in the appearance of a sharp discontinuity between northerly and southerly winds, near and along the coast. The location of this discontinuity is not very accurately simulated by MesoNH-C (near the coast but over the sea), whereas some stations have observed southerly winds during June 23. This is true for instance at Port de Bouc, a coastal station (Fig. 3), where winds are from the south at the end of June 23, whereas simulations predicted northerly winds. Mistral wind is simulated all along June 23 whereas a southerly flux is observed at 15.00 UTC. During the night, winds turn to the north. This departure is also reflected in surface temperatures (Fig. 3), overestimated in the simulation of June 23, since southerly winds from the sea are cooler than northerly ones. This is related to mistral decrease late 
(a)

Port de Bouc 06/23-24/01

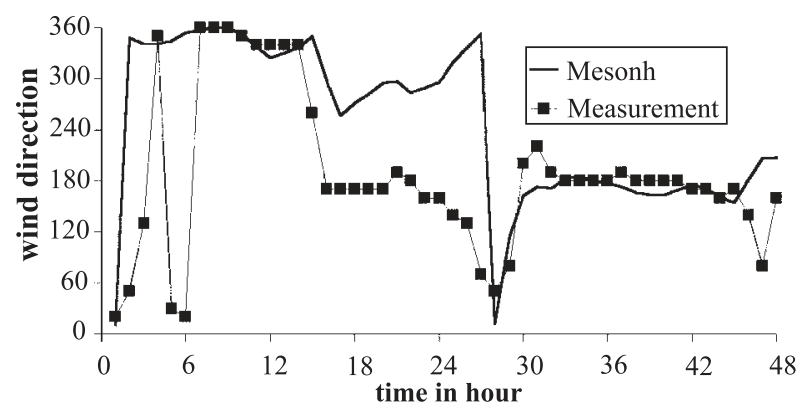

(b)

Port de Bouc 06/23-24/01

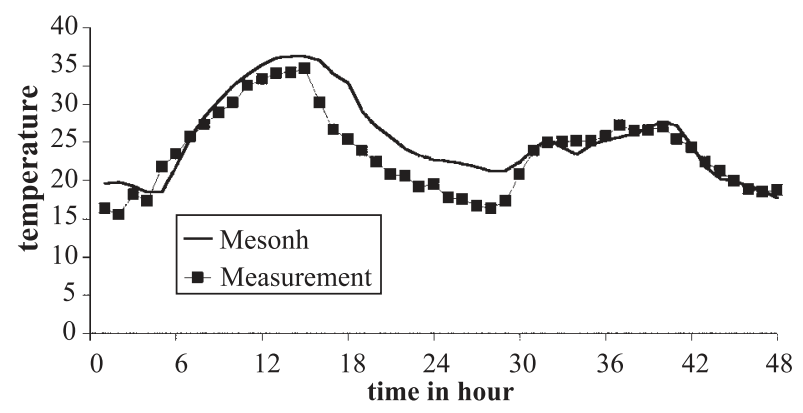

Fig. 3. Comparative evolutions of (a) wind directions (in degrees) and (b) temperatures (in ${ }^{\circ} \mathrm{C}$ ) on June 23 and 24 at Port de Bouc (squares for measurements, solid line for the model).

on June 23. Due to land-breeze onset, this discrepancy is a minimum at 4.00 UTC on June 24 (Fig. 3). In their study of eastern Spain, also characterised by a complex topography, Salvador et al. (1999) have required a $2-\mathrm{km}$ grid size to account for $95 \%$ of terrain variance. However, a $3-\mathrm{km}$ resolution still seems reasonable to depict the main wind characteristics which do not dramatically change on June 23. The same also holds on June 24 for correct sea-breeze simulation with a quite satisfactory correspondence between winds and temperatures (Fig. 3).

\subsection{Sea-breeze regime onset on June 24}

In contrast to June 23 , June 24 is characterized by sea-breeze circulations over the Escompte domain. In fact, there is a complex interplay between synoptic northerly winds and local flows. These local flows originate from various surface heterogeneities in the Escompte domain, such as the Berre pond (a large inland water surface), topography, coastal curvature, urban centres, etc. (Pielke et al., 1992). In this section, we first validate our dynamical simulations in such a complex setting against surface and aircraft measurements, a prerequisite before considering chemical data.

Fig. 4 displays wind vectors at 9.00 and 15.00 UTC on June 24. At 9.00 UTC (upper diagram) north of Berre, a convergence area appears between the mistral flux and the sea- 


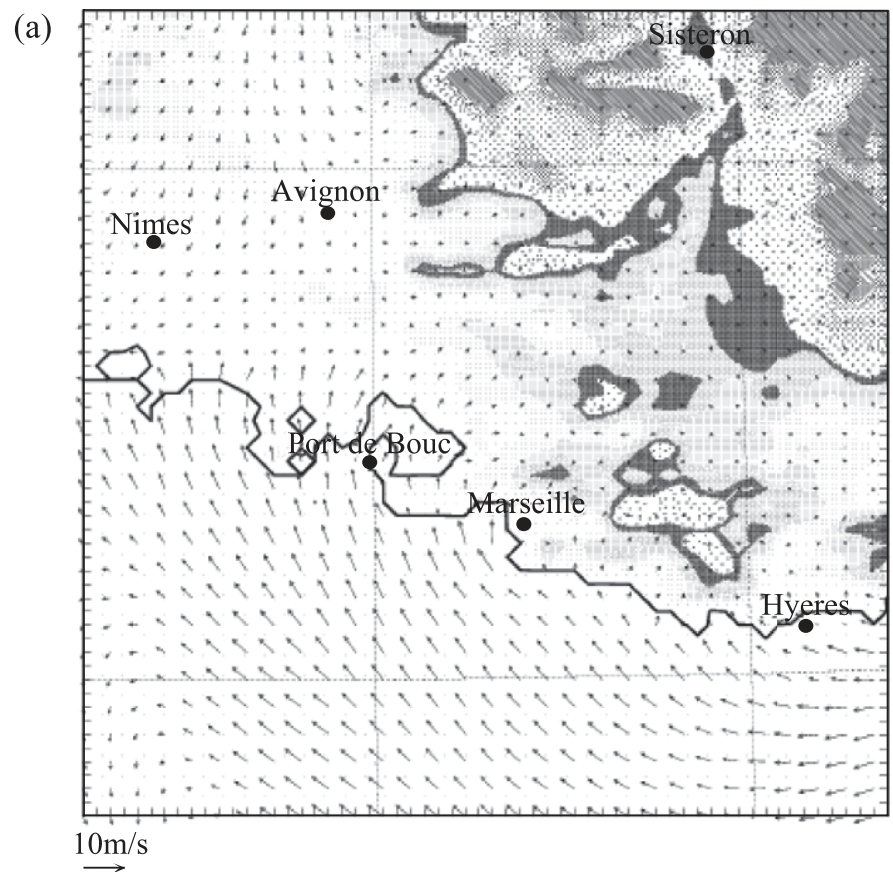

(b)

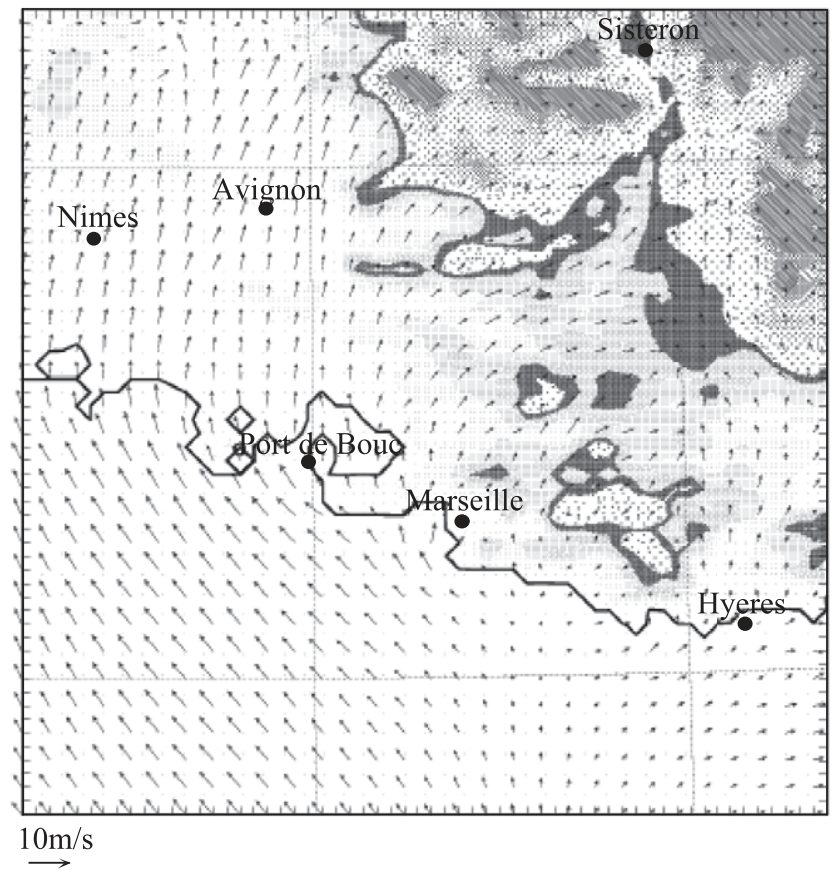

Fig. 4. Wind vectors at 9.00 UTC (a) and 15.00 UTC (b) (vector length at the bottom left is for $10 \mathrm{~m} / \mathrm{s}$ ). 

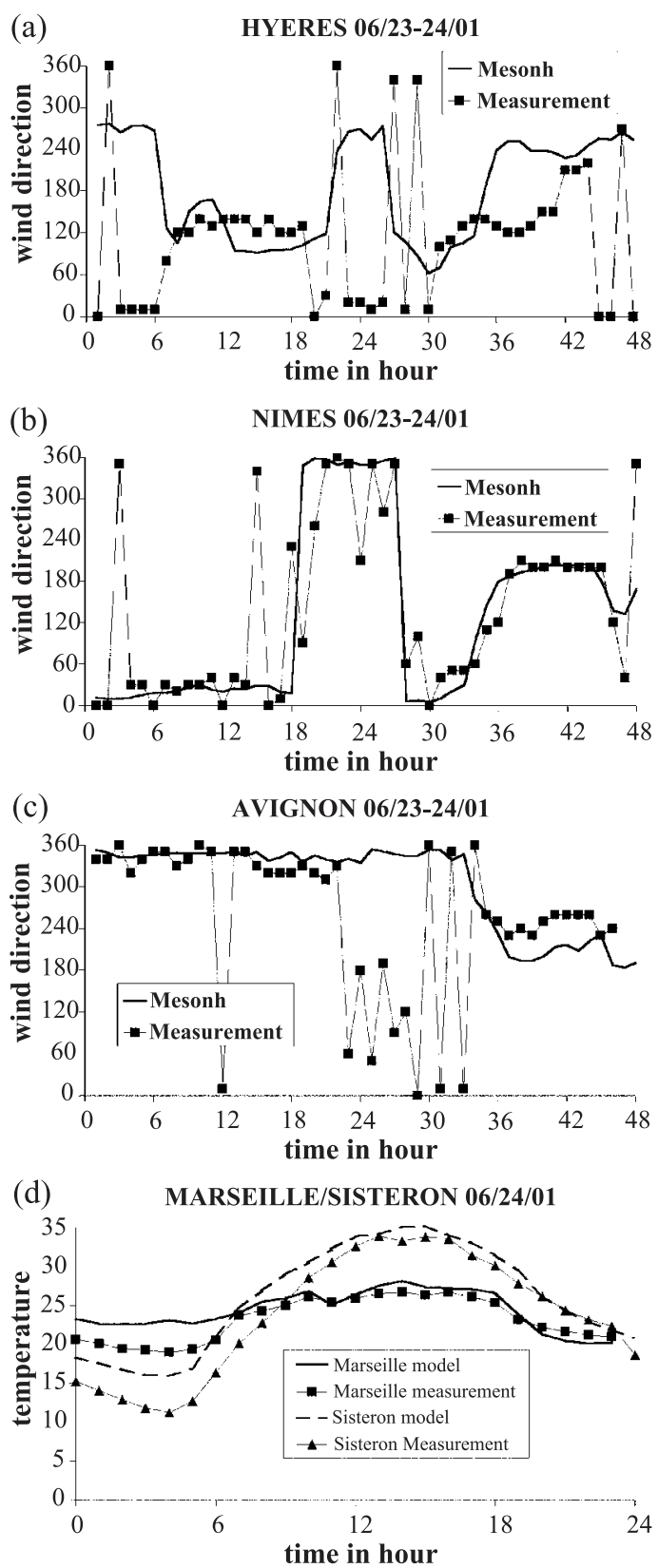

Fig. 5. Comparative evolutions of wind directions (in degrees) on June 23 and 24 at (a) Hyeres, (b) Nîmes, (c) Avignon (squares for measurements, solid line for the model) and (d) temperatures (in ${ }^{\circ} \mathrm{C}$ ) on June 24 at Sisteron and Marseille (squares for measurements and solid line for the model at Marseille, triangles for measurements and dotted line for the model at Sisteron). 
breeze circulation. The sea-breeze front is blocked along the coast up to Hyeres where coastal orography allows for the southerly flux to penetrate inland. North-east of this front, low wind forces (about $2 \mathrm{~m} / \mathrm{s}$ ) are simulated, especially in the Durance valley. At 15.00 UTC (lower diagram), a southerly flux is observed west of the Berre pond, whereas east of the domain, anticyclonic winds from the south-west blow in the Durance valley. The seabreeze circulation promotes wind forces up to $5 \mathrm{~m} / \mathrm{s}$. North of Hyeres, southerly winds are also observed.

Accurate timing of the sea-breeze progression within the domain is both observed and simulated (Fig. 5), thus, the sea-breeze first appears at Hyeres at 6.00 UTC before rapidly extending west of the domain. Southerly winds are observed at Nimes at 11.00 UTC, then afterwards covering the whole domain. At the inland station of Avignon, southerly fluxes appear at 13.00 UTC, the sea-breeze front then moving north, west of the domain. East of the domain, winds are from the south-west this whole day.

As for temperatures on June 24, inland values reach $30-35{ }^{\circ} \mathrm{C}$ at Sisteron, with typical diurnal evolution, against $23{ }^{\circ} \mathrm{C}$ only at coastal Marseille subject to cooler marine air and reduced diurnal temperature amplitude (Fig. 5).

Several aircraft were operated on June 24 over the Escompte domain. Let us focus upon the Merlin flight number 17, between 10.25 and 12.55 UTC. From 10.40 UTC to 12.00 UTC, the flight level run is at $878 \mathrm{hPa}$, north of the Berre pond, from Avignon to Cadarache, with both observed and simulated north-westerly $\left(240-300^{\circ}\right)$ winds (Fig. 6).
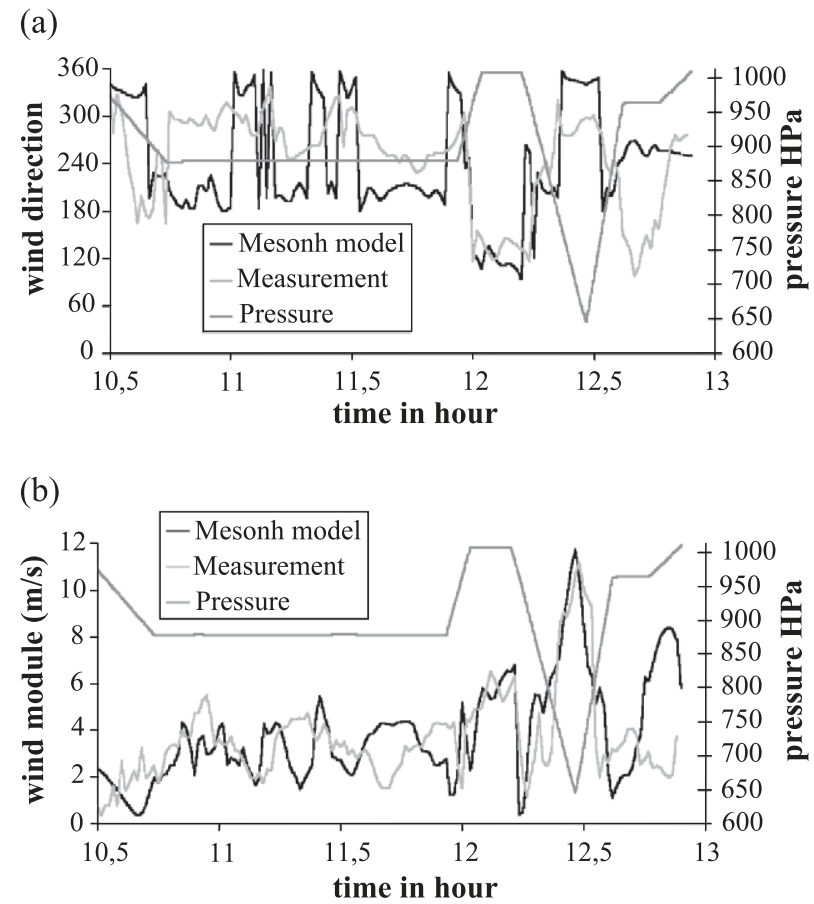

Fig. 6. Time series during the Merlin 17 flight for (a) wind direction and (b) wind module (scale in $\mathrm{m} / \mathrm{s}$ at the left) (model in black, measurements in light gray and pressure level in dark gray). 
Then, at 12.00 UTC the Merlin aircraft flew at the $1006 \mathrm{hPa}$ level, south of Marseille. There, south-easterly surface winds $\left(120^{\circ}\right)$ were again observed, the same as previously recorded at surface stations. In Fig. 6, both observed and simulated wind forces are about 5 $\mathrm{m} / \mathrm{s}$. Afterwards, the Merlin aircraft performed a vertical sounding between 1006 and 650 $\mathrm{hPa}$. The sea-breeze return flow was clearly observed and simulated at $750 \mathrm{hPa}$, with north-westerly winds and wind forces increasing to $12 \mathrm{~m} / \mathrm{s}$.

Measurements and simulated results generally agree, the latter running for an extended period of three days, thus giving some support to the reliability of the MesoNH-C model and its surface schemes.

Now, we examine both the local and regional effects on the complex pollution episode of June 24.

\section{Chemical transport during the meteorological transition from June 23 to June 24}

In Section 3, due to the synoptic meteorological situation and the presence of coastal mountains around the Western Mediterranean Basin, pollutant layering is observed in the low troposphere. Thus, an ozone layer at $1500 \mathrm{~m}$, first simulated north of Barcelona, moves towards the Escompte domain (Fig. 2).

First, we will study the local pollutant plumes appearing in the Escompte domain due to internal pollutant sources. Then, we will see how the regional polluted layer above, advected from the west, has influenced the pollution episode observed on June 24 in this domain through interaction with the local sources.

\subsection{Local pollution plumes from the Berre and Marseille sources}

In Fig. 7, at 12.00 UTC, NOx surface fields and superimposed wind vectors are displayed with the $10 \mathrm{pbb}$ NOx isocontour delineating the main plumes issued from the Berre pond (NOx concentrations over $20 \mathrm{ppb}$ near the sources) and Marseille. The plume from Berre is driven to the north by the sea-breeze circulation. As for the Marseille plume, it is channelled within the Arc valley. Line $\mathrm{C} 1$ is the horizontal trace of the vertical cross sections shown in Fig. 8.

In Fig. 8 , the 2 ppb NOx isocontour has been drawn, delineating the horizontal extent of the Berre plume. Its thickness is $300 \mathrm{~m}$ at Berre and at the coast, against $800 \mathrm{~m}$ south of Luberon. Around this latter massif, boundary layer thickening determines enhanced vertical mixing as will be seen.

In Fig. 8, the ozone concentration field associated with the previous NOx concentration field has been drawn. Ozone formation is promoted due to high temperatures (over $30{ }^{\circ} \mathrm{C}$ ), intense photochemistry and strong emissions (Sillman and Samson, 1995). One further observes a complex vertical stratified structure. At the surface first, one can see the ozone plume from Berre. Higher up, at $900 \mathrm{~m}$, a low concentration ozone layer is observed, issued from north-west of the domain. Then, at $1500 \mathrm{~m}$, another ozone layer (70 ppb) advected from the west and already displayed in Fig 2, is observed, which is caught up by the thickening boundary layer near Luberon. For the sake of brevity, the origins of these ozone layers (not reported here) have been determined using the back trajectory technique 


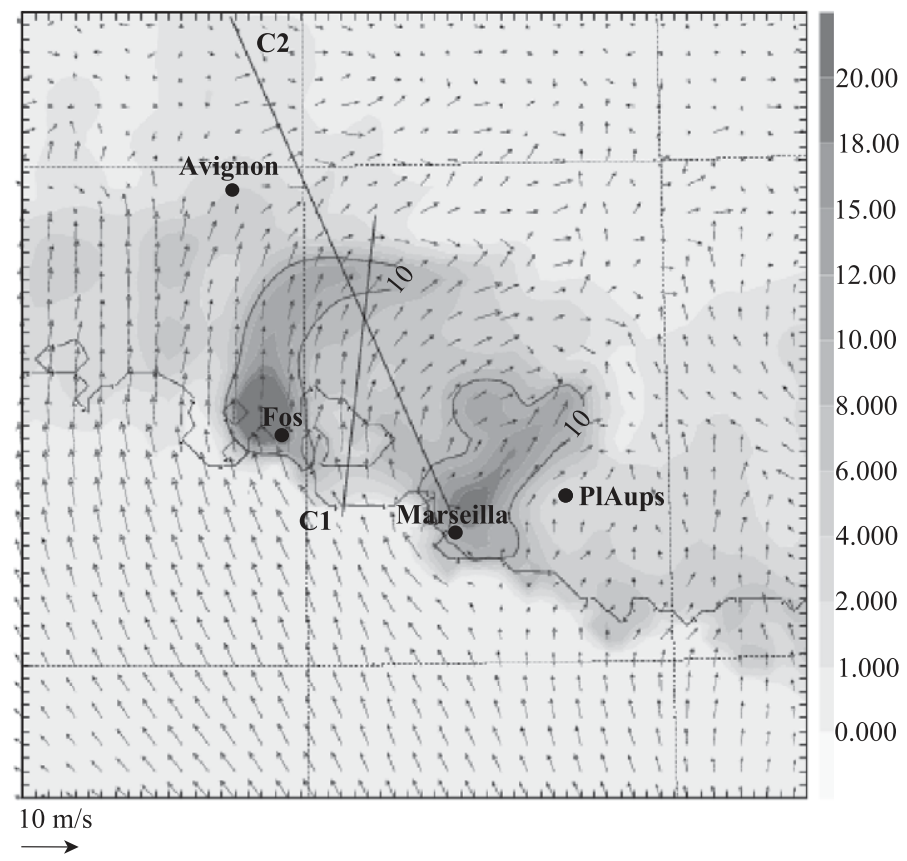

Fig. 7. NOx concentration field (scale in ppb at the right) superimposed upon wind vectors (scale at bottom left) on June 24, at 12.00 UTC. Line C1 and C2 are the surface traces of the vertical cross-section in Figs. 8 and 11, respectively.

in Section 2. In the following, such trajectories will be used for the lidar profile analysis at Aix les Milles (Section 5.3).

At the Fos industrial station by the Berre pond, ozone concentrations are quite well simulated with ozone levels around 60 ppb during the day (Fig. 9). In urban zones, such as Marseille (Fig. 9), there is a good agreement too between measured and simulated ozone concentrations.

\subsection{Regional transport of ozone layers}

In Section 3, an ozone layer has already been identified approaching the Escompte domain from the west. At 8.00 UTC, in the morning, it is located from the Balearic islands to south of the Massif Central in France. Due to early enhanced local thickening of the boundary layer above Montpellier and the relatively low altitude of this ozone layer base, ozone is soon entrained downwards. So, at Montpellier, one observes an ozone rate increase of about $20 \mathrm{ppb} / \mathrm{h}$ as soon as 8.00 UTC (Fig. 10), which quite well simulated but too early to be attributed to photochemistry only. Such a phenomenon has been invoked by Neu and Kunzle (1994). Reitebuch et al. (2000) have concluded that vertical turbulent mixing is the only possible cause for ozone concentration decrease in the residual layer, early in the morning. In this situation, Meso-NH-C shows that, in the morning, the boundary layer is already thick enough over Montpellier to penetrate the base of the upper 
(a)

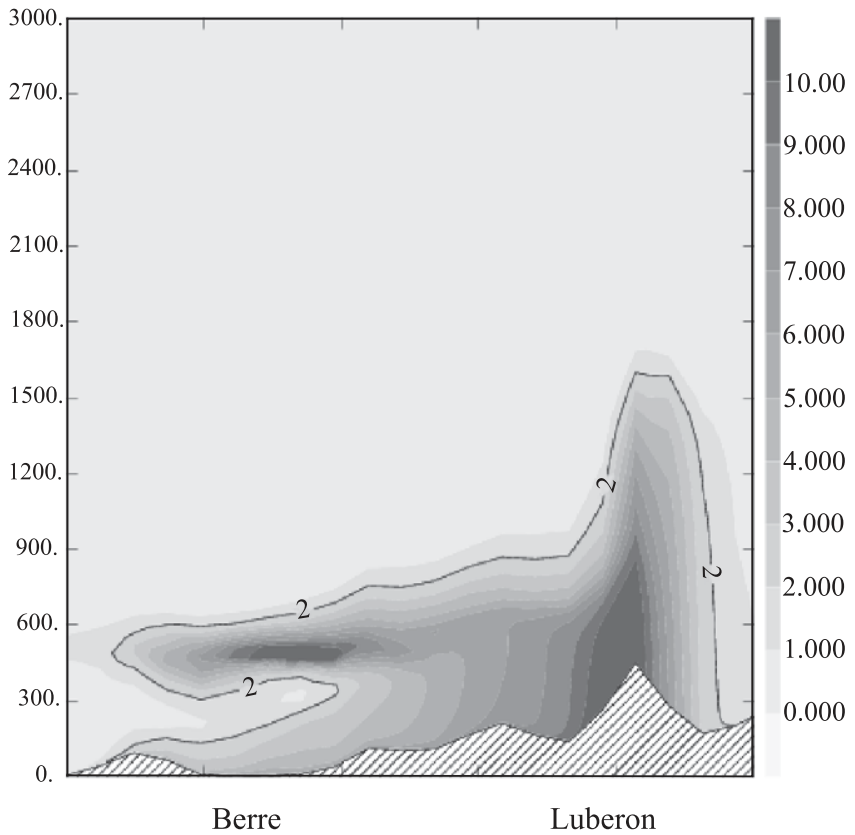

(b) 300

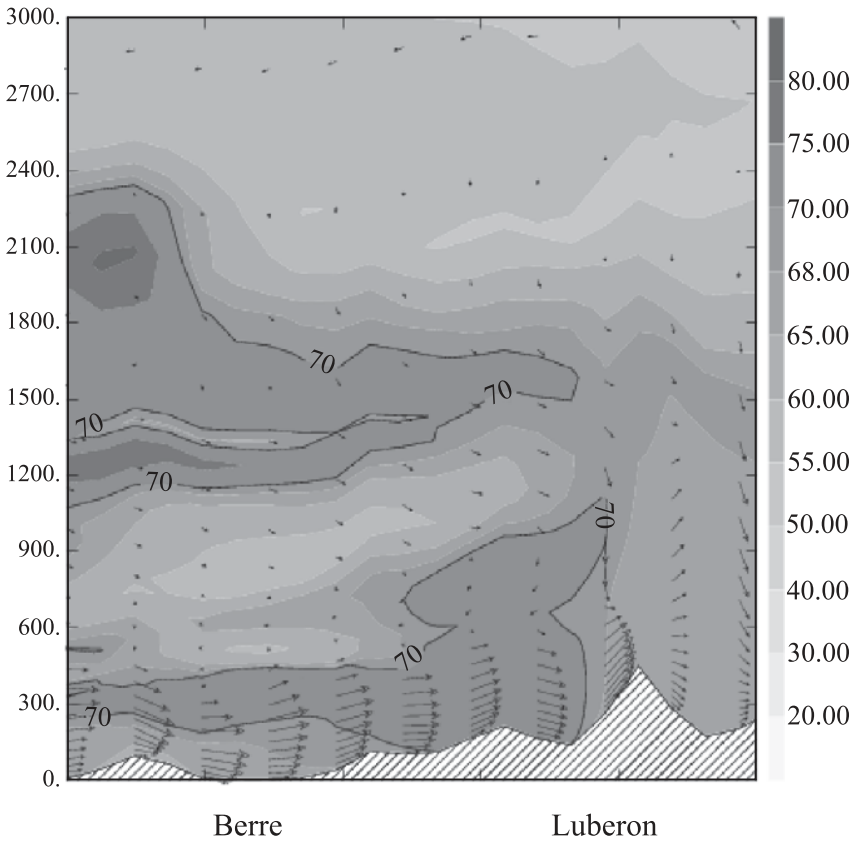

Fig. 8. Vertical cross sections along line $\mathrm{C} 1$ in Fig. 7: (a) for NOx and (b) for $\mathrm{O} 3$ fields (in ppb) at $12.00 \mathrm{UTC}$. Wind vectors are superimposed upon the ozone field (scale at bottom right). 
(a)
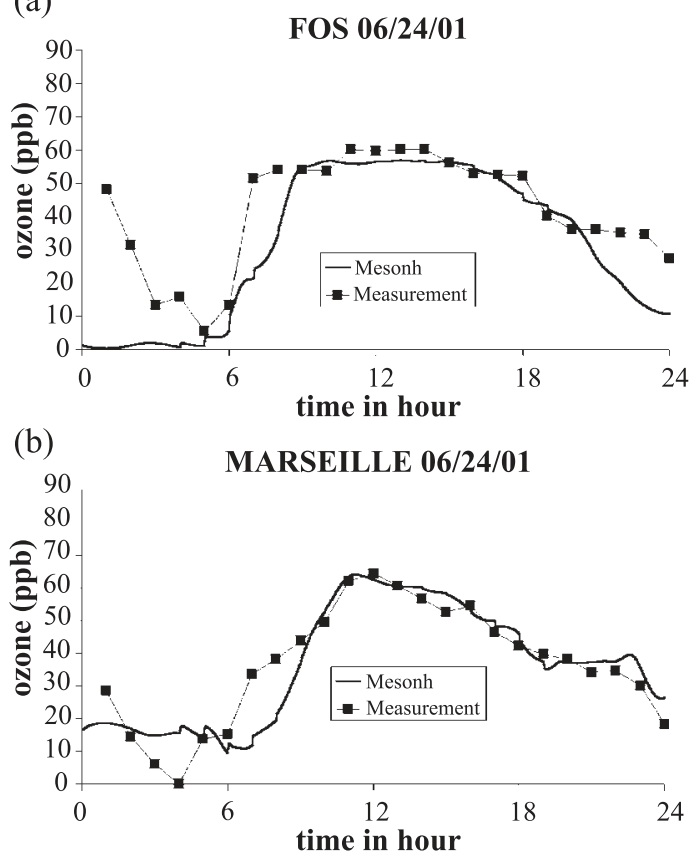

(c)

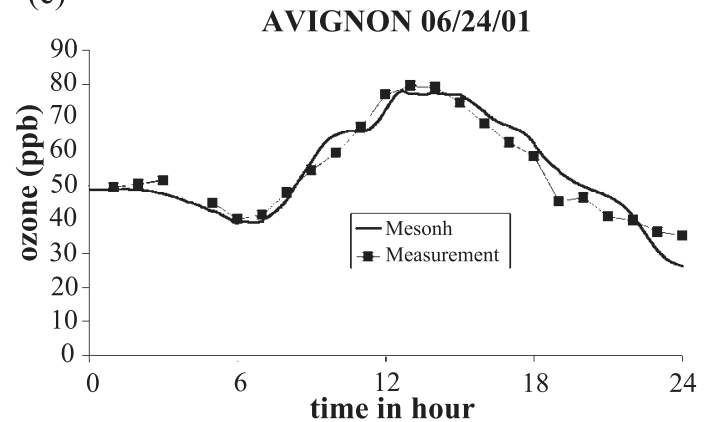

(d)

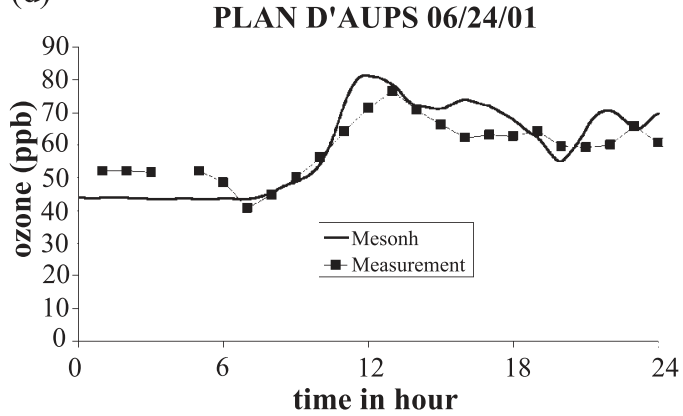

Fig. 9. Ozone time series (scale in ppb at the left) for June 24 at (a) Fos, (b) Marseille, (c) Avignon, (d) Plan d'Aups (squares for measurements, dark curve for Meso-NH-C). 


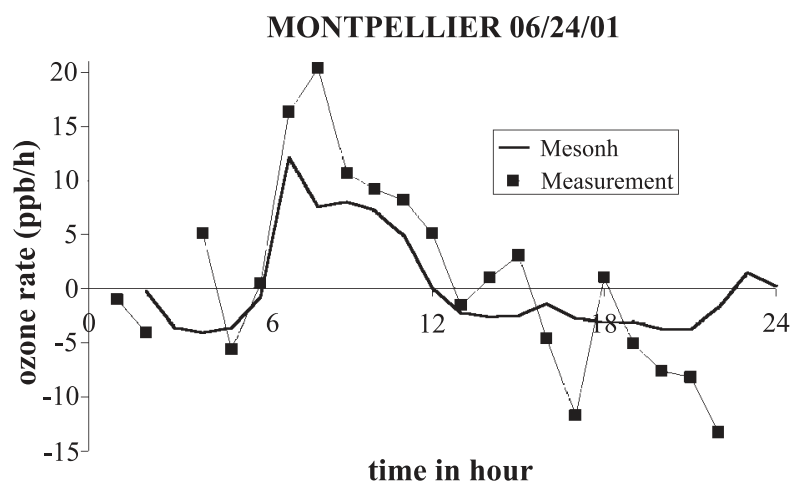

Fig. 10. Ozone rates at Montpellier (scale in $\mathrm{ppb} / \mathrm{h}$ at the left) on June 24 (squares for measurements, dark curve for Meso-NH-C).

ozone layer thus entraining ozone downwards. This entrained ozone, reaching down to the surface, and trapped between the Massif Central barrier and the southerly flux moves to the east, towards the Escompte domain, for a 4-h period.

Avignon is a very interesting station, since it combines both direct arrival of this ozone layer at the surface and the downwind ozone entrained from above (Fig. 9). Fig. 11 displays the vertical cross section along line $\mathrm{C} 2$ in Fig. 7. The pollutant plume from Berre is clearly delineated by the 2 ppb NOx isocontour. We also observe the Marseille NOx plume at the left. On the right, north of Luberon, one does not observe the pollutant plumes from Berre and Marseille, though high ozone concentrations are still observed. At the surface, westward advected ozone interacts with ozone entrained downwards from $1500 \mathrm{~m}$ due to thickening of the boundary layer at 12.00 UTC.

The ozone layer previously observed on June 23 near the Iberian coast reaches the Escompte domain in altitude. Plan d'Aups, near Marseille is one of the highest station (650 $\mathrm{m}$ ), east of the Escompte domain. The urban plume is clearly seen arriving at 12.00 UTC, with ozone levels around $80 \mathrm{ppb}$ (Fig. 9). Later on, in the afternoon and even at night, the ozone levels (60-70 ppb) do not much decrease, which is quite well captured by the model. This is due to the arrival of the ozone layer in altitude at that elevated site, as more generally over the whole Escompte domain. In Fig. 14, the displayed back-trajectories from Plan d'Aups at 16.00 UTC denote air masses reaching this station from high levels west of the domain: these air masses are also shown in Fig. 2.

Using passive tracers, one can represent the vertical movement of air masses during $1 \mathrm{~h}$. In Fig. 12 an horizontal section at $700 \mathrm{~m}$ a.s.l is shown just above Plan d'Aups at 12.00 UTC, with the vertical displacement $z-z_{0}\left(z\right.$, height of the map $(700 \mathrm{~m})$ and $z_{0}$, the initial altitude of air parcels). At Plan d'Aups, air masses arriving at $700 \mathrm{~m}$ at 12.00 UTC were approximately 100-200 m below $1 \mathrm{~h}$ before. At 12.00 UTC, ozone at Plan d'Aups is mainly from urban sources, these sources being located below Plan d'Aups: Fig. 12 illustrates the vertical ascent of this ozone plume. West of the domain, the sea-breeze front is visualized by the passive tracers and ascent of the air masses. It is important too to notice the general subsidence field inland, east of the domain, which persists during the afternoon. This situation is in agreement with the observation of Millàn et al. (1997, plate 5). 
(a)

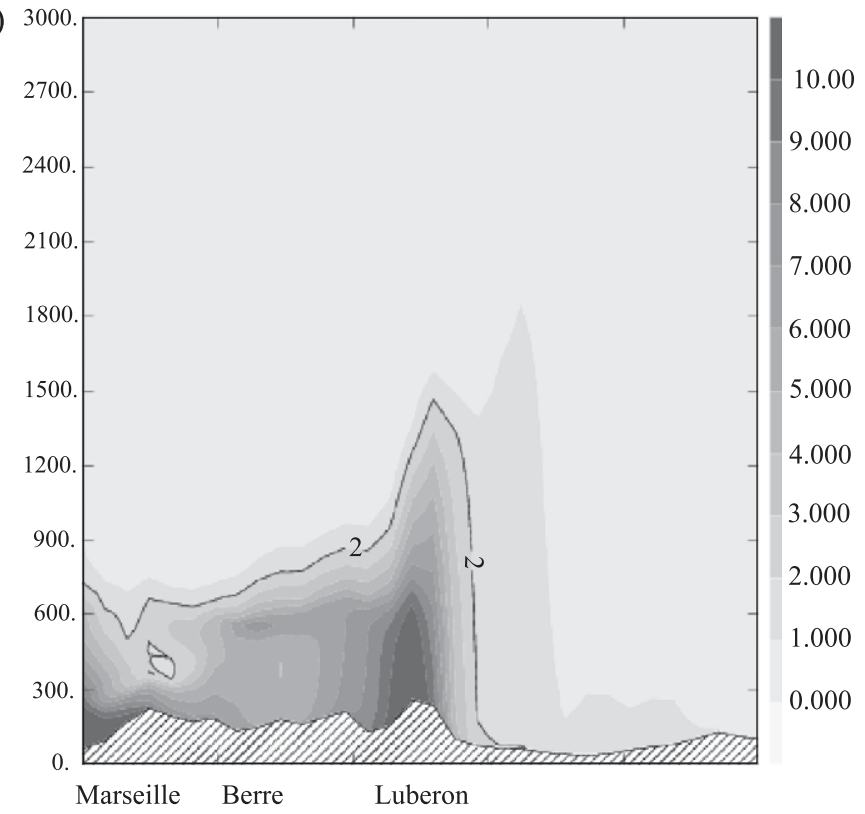

(b)

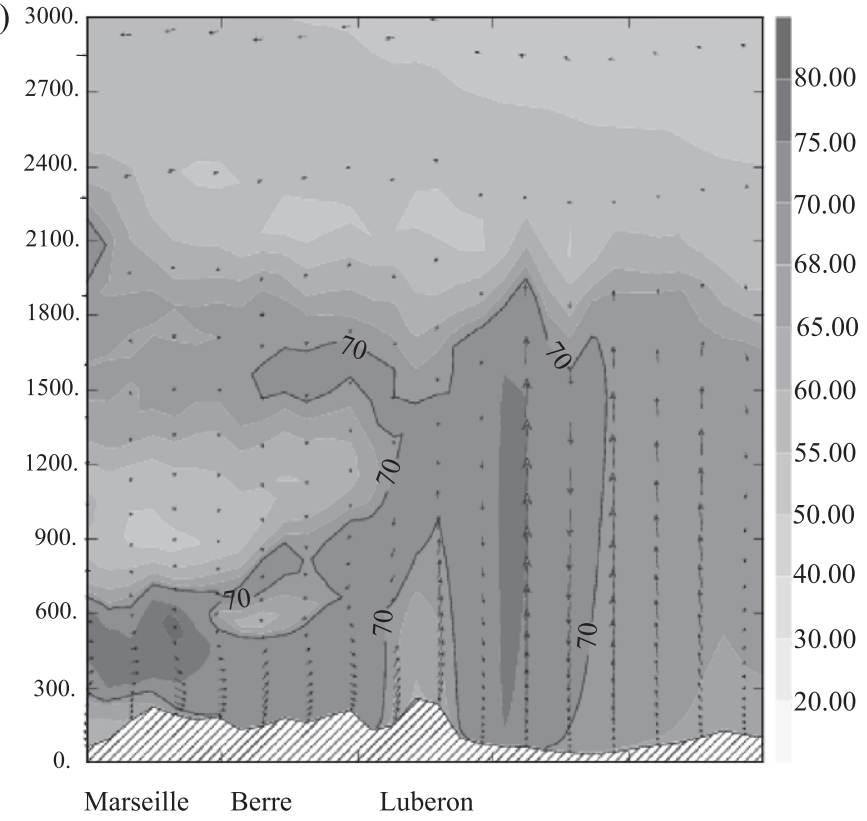

Fig. 11. Vertical cross sections along line $\mathrm{C} 2$ in Fig. 7 for: (a) NOx and (b) $\mathrm{O} 3$ concentration fields (in ppb) at 12.00 UTC. Wind vectors are superimposed upon the ozone field. 


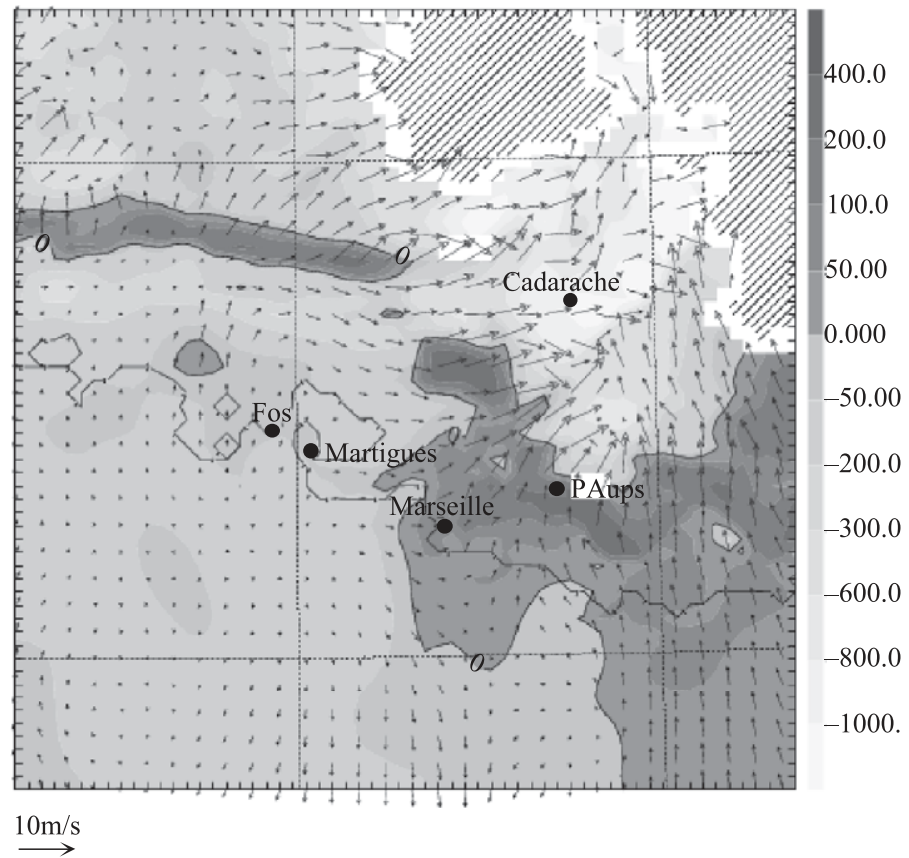

Fig. 12. Map of net vertical algebraic displacement $\left(z-z_{0}\right)$ for Lagrangian air parcels during $1 \mathrm{~h}$, at $700 \mathrm{~m}$ a.s.1. and at 12.00 UTC (scale in meters at the right).

Recirculation of the ozone layer initialized in the previous days near Barcelona is closed here with this subsidence in the Escompte domain, emphasizing the impact of ozone pollution on June 24 at a regional scale.

\subsection{Evolution of the ozone vertical profile near the Berre pond}

The previous sections have detailed the interactions between local ozone sources, regional ozone advection and subsidence within the Escompte domain. The emerging general picture is the complex evolving three-dimensional structure of the lower troposphere over the Marseille/Fos-Berre area in terms of dynamics and chemistry. In the following, further supporting argumentation is found in the evolving vertical atmospheric structure depicted by the Alto lidar measurements performed at Aix-les-Milles on June 24. This station, located west of Sainte Victoire, near the Berre pond and north of Marseille (Fig. 1), is subject to sea-breeze circulations.

First, a generally good agreement is found between the observed and simulated ozone vertical profiles over Aix-les-Milles (Fig. 13). More specifically, the nocturnal boundary layer (below $100 \mathrm{~m}$ ) is characterized by weak ozone levels due to NOx accumulation until 7.00 UTC. Afterwards, between 7.00 UTC and 12.00 UTC, the boundary-layer progressively deepens up to $500 \mathrm{~m}$, while being confined below southerly marine air masses. Due to increasing photochemistry, the ozone level rises up to $70 \mathrm{ppb}$. After 16.00 UTC, a new boundary layer stratification appears, due to reduced surface heating, together 

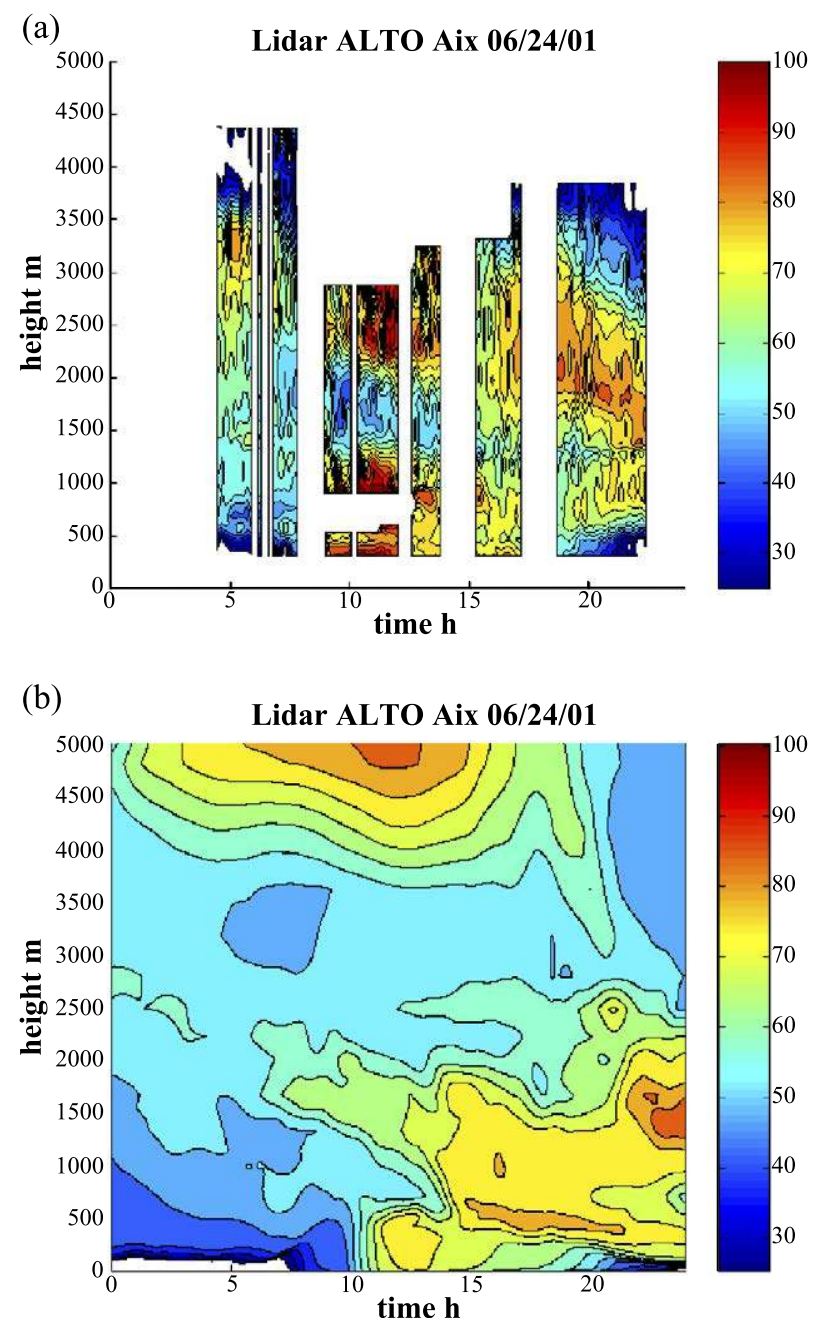

Fig. 13. Comparative lidar (a) measurements and (b) ozone simulation (scales in ppb at the right) at Aixles-Milles.

with decreasing photochemistry and ozone levels. Higher up, at $16.00 \mathrm{UTC}$, a residual 70 ppb ozone layer is observed between $500 \mathrm{~m}$ and $1500 \mathrm{~m}$, not of local origin, since appearing above the mixed layer. Moreover, such a layer is not found in the morning between 0.00 UTC and 10.00 UTC. In the observed and simulated lidar profiles, these two above layers can clearly be identified. We now determine their separate origins using the previous lagrangian tracers.

Fig. 14 displays the horizontal projections of back trajectories reaching Aix-les-Milles, respectively, at 5.00 UTC, 10.00 UTC, 15.00 UTC, 20.00 UTC on June 24. In this figure, the respective arrival heights at Aix-les-Milles are the surface (black), $500 \mathrm{~m}$ (red), $1000 \mathrm{~m}$ (green), $1500 \mathrm{~m}$ (blue), $2000 \mathrm{~m}$ (light blue), $3000 \mathrm{~m}$ (pink) and $4000 \mathrm{~m}$ (yellow). It 
(a)

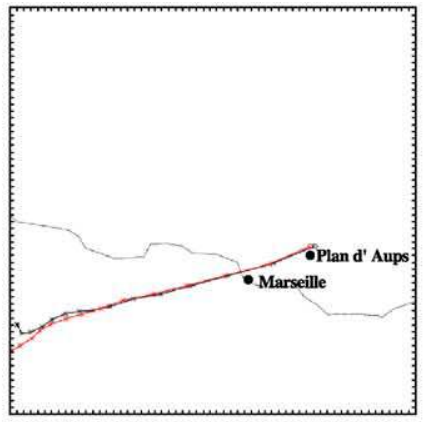

(c)

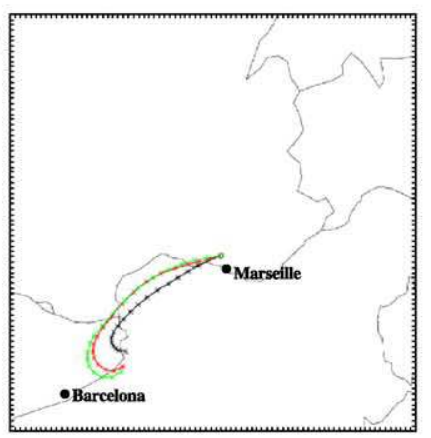

(e)

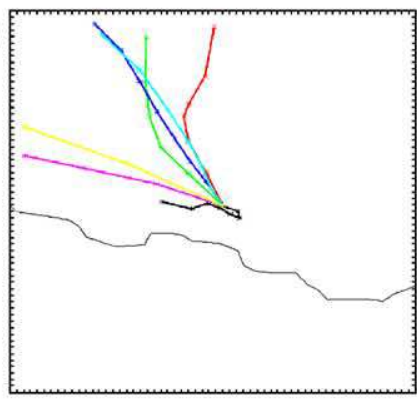

(g)

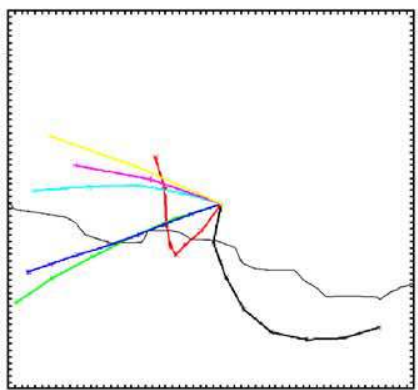

(b)

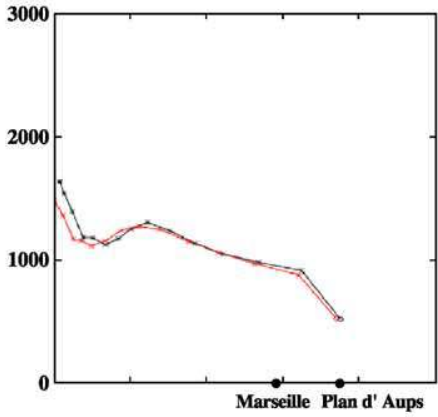

(d)

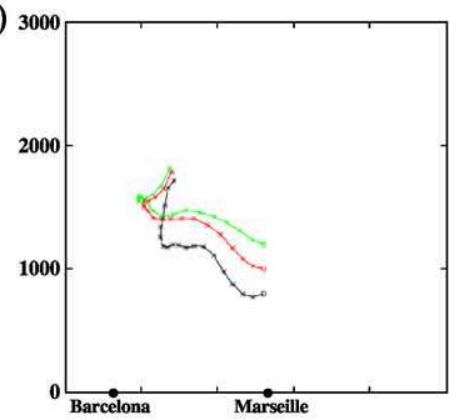

(f)

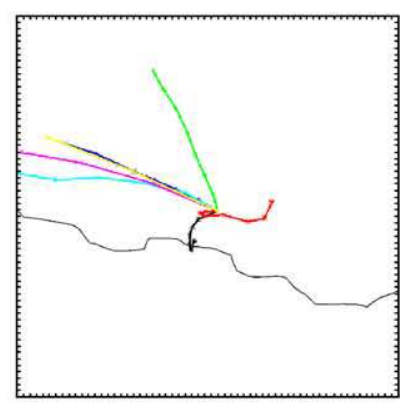

(h)

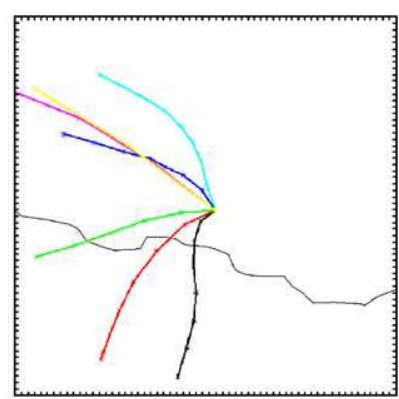

Fig. 14. Horizontal (a) and vertical (b) projections as seen from the south for back trajectories arriving at Plan d'Aups at 16.00 UTC. Horizontal (c) and vertical (d) projections of back trajectories respectively arriving at 800 , 1000 and $1200 \mathrm{~m}$, on June 24 at Aix-les-Milles in the large simulation domain. Horizontal projections of back trajectories at $5.00 \mathrm{UTC}$ (e), $10.00 \mathrm{UTC}$ (f) $15.00 \mathrm{UTC}$ (g), $20.00 \mathrm{UTC}$ (h). Arrival heights at the surface (black), at $500 \mathrm{~m}$ (red), at $1000 \mathrm{~m}$ (green), at $1500 \mathrm{~m}$ (blue), at $2000 \mathrm{~m}$ (light blue), at $3000 \mathrm{~m}$ (pink) and at $4000 \mathrm{~m}$ (yellow). 
appears that through combination of Figs. 13 and 14, moderate (40-55 pp) ozone levels in altitude have a regional origin from the north-west, whereas surface low ozone levels between 0.00 and 10.00 UTC have a local origin within the Escompte domain. Between 12.00 and $15.00 \mathrm{UTC}$, surface air masses, driven by the sea-breeze regime, advected from the south in the mixed boundary layer as opposed to south-westerly directions above. After 15.00 UTC, the identified upper ozone layer between 500 and $1500 \mathrm{~m}$ has a regional origin from the south-west. Further information is gained in Fig. 14 using back trajectories (respectively arriving at 800,1000, $1200 \mathrm{~m}$ over Aix-les-Milles), computed over the large simulation domain in Section 3. It is clearly seen in this horizontal projection that this ozone layer aloft, originating from the polluted Barcelona area on June 24 at 1.00 UTC between 1500 and $2000 \mathrm{~m}$, is afterwards driven to the north-east over Luberon, before mixing there with the developing convective layer. This example of the evolving lidar vertical structure over Aix-les-Milles illustrates the complex interplay between local and regionally remote ozone sources in the Escompte domain.

\section{Conclusions}

IOP $2 a$ and $2 b$ are typical summer pollution episodes affecting the Marseille/Fos-Berre area, after a mistral outbreak with subsequent deep inland sea-breeze penetration within the upper Durance valley. Complexity of this area in terms of dynamics and chemistry has been outlined, due to its topography and various intense anthropogenic (industrial, traffic, urban) and biogenic emission sources.

Escompte 2001 has been a unique opportunity for intensive surface, aircraft and lidar measurements in the region. This exhaustive database has been used in the present study, together with the two-way nested MesoNH-C model. In terms of ozone fields structure and evolution, all these data and simulations have been required to get a full coherent picture of the ozone field peculiarities in the Escompte domain, on June 24. It was demonstrated that both local and regionally remote ozone production sources and transport are needed, with detailed emission inventories and dynamics in the boundary layer and above. Thus, further to boundary-layer dynamics and chemistry, quite a significant contribution to ozone layering aloft is due to differential transport, subsidence and interaction with the boundary layer. Results in Section 5 have shown that over the sea and coastal regions, there are different layers constituting the stratified lower troposphere, with various local and regional origins. They are transported to the east before diurnal thickening of the boundary layer over land determines mixing of these layers, thus drastically affecting ozone pollution levels at the surface. Thus, similar processes involving either vertical recirculations of the aged air masses have been also documented for Central Mediterranean (Georgiadis et al., 1994; Orciari et al., 1998). More generally, Millàn et al. (1997) have shown that these processes are favoured north of the Mediterranean Basin from Spain to Israel. The evolution of stratified layers not only concerns the middle and upper troposphere (Thouret et al., 2000; Newell et al., 1999), but also the lower troposphere, particularly in anticyclonic conditions. Improved knowledge of this evolution is a key element for air quality predictability and forecasting: this requires strong atmospheric dynamics and chemistry coupling between local, regional and synoptic scales. 


\section{Acknowledgments}

The authors warmly acknowledge J. Escobar, D. Gazen, J. Duron and S. Prieur for their assistance. Computational resources were provided by the Institute for Development and Resources in Intensive Scientific Computer. This work is supported by ADEME and CNRS.

\section{References}

Bougeault, P., Lacarrère, P., 1989. Parameterization of orography-induced turbulence in a meso-beta scale model. Mon. Weather Rev. 117, 1872-1890.

Crassier, V., Suhre, K., Tulet, P., Rosset, R., 2000. Development of a reduced chemical scheme for use in mesoscale meteorological models. Atmos. Environ. 34, 2633-2644.

Cros, B., Durand, P., Cachier, H., Drobinski, Ph., Frejafon, E., Kottmeier, C., Perros, P.E., Peuch, V.H., Ponche, J.L., Robin, D., Saï, F., Toupance, G., Wortham, H., 2004. The ESCOMPTE program: an overview. Atmos. Res. 69 (3-4), 241-279.

Dufour, A., Amodei, M., Ancellet, G., Peuch, V.H., 2004. Observed and modelled chemical weather during ESCOMPTE. Atmos. Res. 74, 161-189 (this issue).

Gangoiti, G., Millàn, M., Salvador, S., Mantilla, E., 2001. Long-Range transport and reciculation of pollutants in the Western Mediterranean during the RECAPMA Project. Atmos. Environ. 35, 6267-6276.

Georgiadis, T., Giovanelli, G., Fortezza, F., 1994. Vertical layering of photochemical ozone during land-sea breeze transport. Nuovo Cim. 17, 371-375.

Gheusi, F., Stein, J., 2002. Lagrangian description of air-flows using Eulerian passive tracers. Q. J. Royal. Meteorol. Soc. 128, 337-360.

Lafore, J.P., Stein, J., Asencio, N., Bougeault, Ph., Ducrocq, V., Duron, J., Fischer, C., Hereil, P., Mascart, P., Masson, V., Pinty, J.P., Redelsperger, J.L., Richard, E., Vila-Guerau de Arellano, J., 1998. The Meso-NH atmospheric simulation system. Part I: adiabatic formulation and control simulations. Ann. Geophys. 16, 90- 109

Masson, V., 2000. A physically-based scheme for the urban energy balance in atmospheric models. BoundaryLayer Meteorol. 94, 357-397.

Millàn, M., Salvador, R., Mantilla, E., Artiñano, B., 1996. Meteorology and photochemical air pollution in southern Europe: experimental results from EC research projects. Atmos. Environ. 30, 1909-1924.

Millàn, M., Salvador, R., Mantilla, E., Kallos, G., 1997. Photo-oxidant dynamics in the Mediterranean basin in summer: results from European research projects. J. Geophys. Res. 102 (D7), 8811-8823.

Neu, U., Kunzle, T., Wanner, H., 1994. On the relation between ozone storage in the residual layer and daily variation in near-surface ozone concentration-a case study. Boundary-Layer Meteorol. 69, $221-247$.

Newell, R.-E., Thouret, V., Cho, J.Y.N., Stoller, P., Marenco, A., Smit, H., 1999. Ubiquity of quasi-horizontal layers in the troposphere. Nature 398, 316-319.

Noilhan, J., Mahouf, J., 1995. The isba land surface parametrisation scheme. Glob. Planet. Change 13, $145-159$.

Orciari, R., Georgiadis, T., Fortezza, F., Alberti, L., Leoncini, G., Venieri, L., Gnani, V., Montanari, T., Rambelli, E., 1998. Vertical evolution of photochemical ozone over greater Ravenna. Ann. chim. 88, $403-411$.

Pielke, R.A., Cotton, W.R., et al., 1992. A comprehensive meteorological modeling system RAMS. Meteorol. Atmos. Phys. 49, 69-91.

Reitebuch, O., Strassburger, A., Emeis, S., Kuttler, W., 2000. Nocturnal secondary ozone concentration maxima analysed by sodar observations and surface measurements. Atmos. Environ. 34, 4315-4329.

Salvador, R., Calbò, J., Millàn, M., 1999. Horizontal grid selection and its influence on mesoscale model simulations. J. Appl. Meteorol. 38, 1311-1329.

Sillman, S., Samson, P.J., 1995. Impact of temperature on oxidant photochemistry in urban, polluted rural end remote environments. J. Geophys. Res. 100, 11497-11508. 
Stockwell, W.R., Kirchner, F., Kuhn, M., Seefeld, S., 1997. A new mechanism for regional atmospheric chemistry modelling. J. Geophys. Res., D 22, 25847-25879.

Thouret, V., Cho, J.Y.N., Newell, E., Marenco, A., Smit, H.G.J., 2000. General characteristics of tropospheric trace constituent layers observed in the MOZAIC program. J. Geophys. Res. 105 (D13), 17379-17392.

Tulet, P., Crassier, V., Solmon, F., Guedalia, D., Rosset, R., 2003. Description of the Mesoscale Non Hydrostatic Chemistry model and application to a transboundary pollution episode between northern France and southern England. J. Geophys. Res. 108 (D1), 4021.

Wickert, B., Schwarz, U., Blank, P., John, C., Kuhlwein, J., Obermeier, A., Friedrich, R., 1999. Generation of an Emission Data Base for Europe 1994, Proc. Eurotrac Symposium 98, vol. 2, pp. 255-265. 